\title{
Murābaḥah-Ta'āwun Financing: An Innovation in Islamic Personal Financing
}

Aminu Sikiru Olanrewaju(1), Saheed Abdullahi Busari(2)

\begin{abstract}
Entrepreneurs, especially in developing societies, which include many Muslim countries among their fold, face a herculean task in up-scaling their businesses due to a lack of capital to procure relevant assets to grow their businesses. The world Islamic banks' competitiveness report (2016) identified poor financial inclusion as one of the critical factors responsible for the uneven distribution of wealth in the Muslim world. This study presents the Murābahah-Ta 'āwun financing product as an innovative addition to the range of financial products available on the Islamic banking shelf to reduce the incidence of poverty. Murābahah-Ta'āwun is operationalized where a group of entrepreneurs contribute funds together under a recognized Islamic bank while allowing every partner access to the fund on a rotational basis for the purchase of an asset according to a pre-defined arrangement. The study highlighted the importance of Murābahah-Ta'āwun as an Islamic financial contract by reviewing relevant extant literature. The proposed product shows that greater financial inclusion can be achieved without recourse to ribä' and thus will reduce poverty among Muslims.
\end{abstract}

Keywords: Murābahah Ta'āwun, Entrepreneur, Islamic Banking, Poverty, Financial Inclusion.

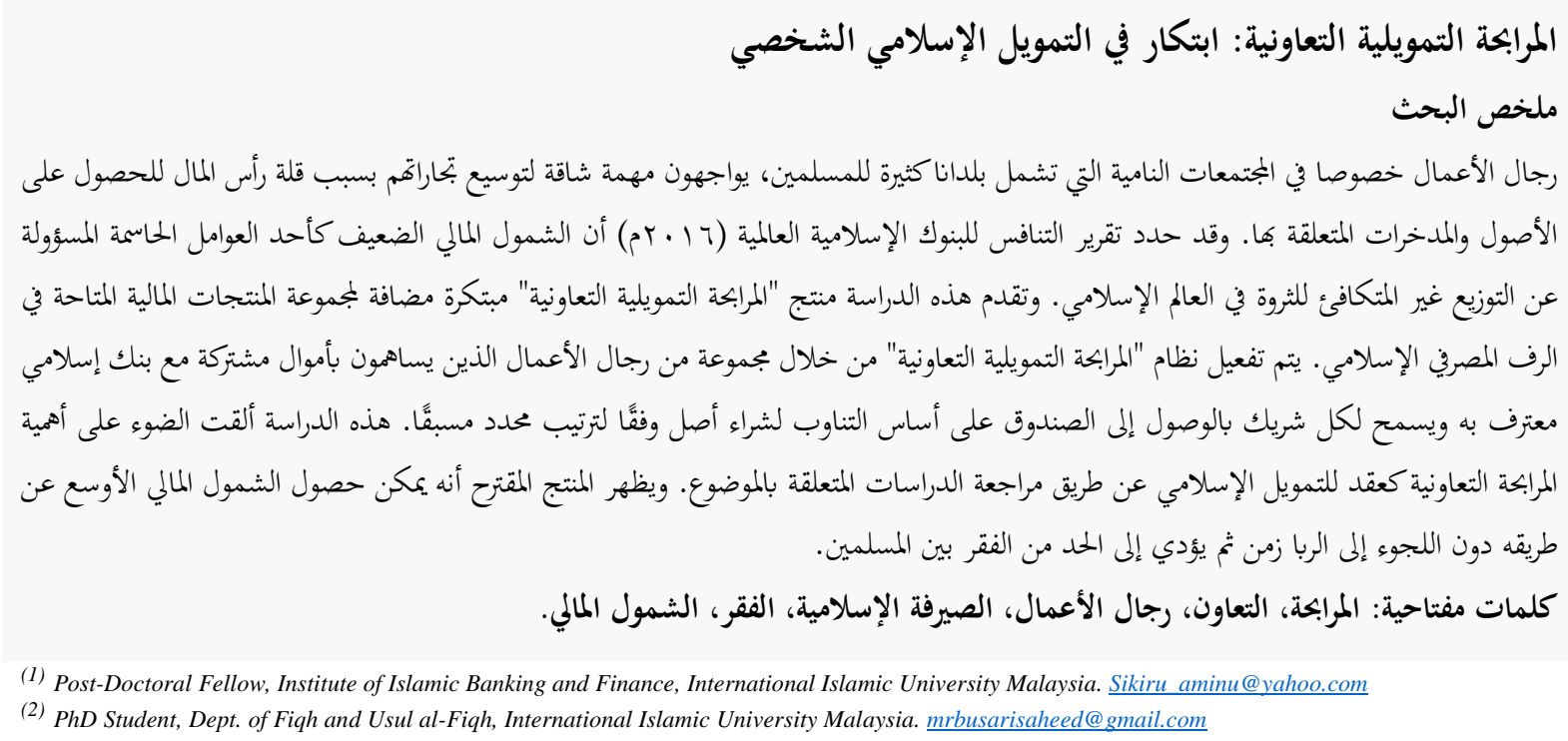

\section{Contents}

1. Introduction

2. The Meaning and Shariah Justification of the Product

2.1 Definition of Murābahah Sales in Islamic Law

2.1.1 Justification of Murābahah Sales

2..1.2 The Condition for Murābahah Sales

2.1.3 Pillars of Murābahah Contracts

2.2 Definition of $\mathrm{Ta}^{c} \bar{a}$ wun

2.2.1 Importance of $\mathrm{Ta}^{c} \bar{a}$ wun in Islam

3. Murābahah Ta' 'āwun Contract

3.1 Proposed Contract Model and its Product Features

3.2 Discussion on Limitations and Potential Shariah Risk of the Proposed Model

4. Conclusion and Recommendation

References

\section{Introduction}

The World Bank G20 summit report of 2010 highlighted that financial inclusion is considered to be one of the core pillars of sustainable development goals, by focusing on how to improve inclusion of marginalized farmers, landless farmers, the selfemployed, migrants' urban slum developers, and women. This effort has triggered the commitment of numbers of countries to the Maya Declaration at the G20 Financial Inclusion Action Plan (Thouraya Triki \& Issa Faye, 2013) which aimed at wealth redistribution to reduce poverty. The report recognized the Islamic finance industry as an important niche that creates financial interventions towards alleviating the challenges of poverty in Muslim populated areas of Asia and Africa. 
In line with the above assertions, Imam and Kpodar (2016) provided empirical analysis which related that despite the small size of the Islamic banking industry, compared to conventional banking and the overall economy, Islamic banking showed a positive relationship with economic growth. Léon and Weill (2017) added that Islamic banking development provides better access to financing in areas where conventional banking is lacking. The emergence of the conversion of conventional banks into fully-fledged Islamic banks and the adoption of the window have also fulfilled the needs of below of pyramid (BOP) citizens by providing reliable service delivery, easy accessibility and convenience for the customers, and flexible transactions which operate on structured regulations.

However, Mughal (2017) highlighted that the finance of Micro-businesses has been neglected in the Islamic banking world as it has only $1 \%$ of the $\$ 2.7$ trillion market share of the Islamic finance industry, whereas small and medium enterprises (SMEs) are closest to the grassroots and are the growth engine of the economy. Imam and Kpodar (2016) emphasized that there should be improved access to deposits that can ensure adequate capital accumulation and deepen financial inclusion. In the world competitiveness report, Young (2010), noted that religious belief and concern for non-shariah compliance are one of the major reasons responsible for financial exclusion in many Muslim dominated nations with widespread conventional banking services (Ernest \& Young 2013). Hanudin et al (2011), focusing on personal financing observed that Islamic banking and finance products and services are based on the precept of Islamic ethics by offering products that consider the needs of the customers without violating the fundamental principles of Shari'ah, unlike conventional banks where profit maximization is the main focus of their relationship with their customers.

In lieu of the above, this paper proposes Murābahahah-Ta'āwun as an innovative product designed towards alleviating poverty and improving the financial inclusion of Muslims and other customers of Islamic Financial Institutions (IFIs). The concept allows a group of entrepreneurs (for example, an association of bakers) in need of similar assets to further the course of their business by entering into a contract with an Islamic bank to contribute funds at certain regular intervals and access the funds on a rotational basis for the agreed asset. In this arrangement, the bank, on one hand, acts as the custodian of the group's regular contributions and collects a service charge. On the other hand, the bank acts as a financier, sourcing funds to obtain the asset on behalf of the group before the completion of their contributions. The bank makes additional income from the inputted mark-up over the cost of the requested asset. At the expiration of the contribution arrangement, members of the group will gain ownership and possession of their individual assets. Murābaḥah means an undertaking by a seller to disclose the cost-plus mark-up price to be sold to a buyer, while the Ta'āwun is a joint cooperation among a group of people to create benefits for members of their group. These two concepts are deeply rooted in Islamic heritage as encouraged and permissible activities based on certain criteria and standards.

The rest of the paper is organized as follows: Section 2 discusses the Shariah justification of the product. Section 3 presents the proposed contract model for the product and its characteristics. Sections 4 discusses the limitations and potential Shariah risks of the proposed model and lastly, section 5 provides the recommendation and conclusions of the study.

\section{The Meaning and Shariah Justification of the Product}

The proposed Murābahah-Ta'āwun financing product is developed from two different and related concepts: 1- Al-Murābaḥah and 2- At-Ta'āwun. The two concepts could be traced to certain evidences from the Qur'ān and Hadīth of the Prophet (PBUH) and other sources of Shariah.

\subsection{Definition of Murābahah Sales in Islamic Law}

Murābahah in the Arabic language is an adjective derived from the verb rābaha, from the pattern of mufā'alah, which means growth or increase in trade. The term Murābahah is derived from Ribh which means an increase, gain or profit. Technically, Murābahah refers to an increase over an asset or capital 
investment in a business. Hence, Murābaḥah is a permissible concept in an Islamic financial contract as long as it fulfills all the conditions stipulated in the Shariah. (ISRA, 2010) Hence, Murābahah is an act of mark-up pricing or increase over sale. (Ahmmad 'Ali, 1987).

According to Islamic jurists, Murābaḥah occurs when seller's mark-up an additional amount of profit or gain over a product to be sold to buyers. (Al-Kasānī, 1986).

\subsubsection{Justification of Murābahah Sales:}

Most Islamic jurists permit Murābahah sales based on certain evidences from the Quran, hadith, commercial custom and social needs.

In the Qur'ān, Allah says: "But Allah has permitted trade and has forbidden interest". [AlBaqarah: 275].

In the same vein, in the hadith of the prophet PBUH "It was said, O Messenger of Allah, what is the best earning? He said, that which a man worked with his hand and every sale is justified" (Ahmad bin Hanbalī, 1994).

According to Jamāludin Al-Zayla‘̄i, Murābahah is the transfer of ownership of the first contract at the first price with an increase or make-up profit. Commercial custom and social needs are one of the justifications of this contract of sale. Murābahah allows those that lack business skills to rely on professional traders to provide for certain products to meet the daily needs of others. However, the sales must be based on trust without deception because the buyer relies on the competency of the seller to deliver the correct product (Jamāludin 1995).

\section{2..1.2 The Condition for Muräbahah Sales:}

To carry out the contract of Murābahah, certain important conditions have to be met for it to fulfil the Shari'ah requirements (Jamāludin 1995). The Islamic laws of contract stipulate that the capital invested must be known and the initial contract must be sound and valid. Also, the contract must be free from any form of interest (Ribā), ambiguity and deceptions. Furthermore, the Shariah requirements stipulate that adequate explanations should be provided by contractual parties on any default, future clauses and changes arising from reduction and addition to the sales contract.

\subsubsection{Pillars of Murābahah Contracts}

Generally speaking, there are four pillars in Murābahah contract. These pillars comprise: the seller is the person who sells the merchandise, the buyer is the person who buys the merchandise, and the merchandise are the goods the seller offers in exchange of the price paid by the buyer with offer and acceptance. It is necessary in murābahah sales that the offer by a party to sales must be in agreement with acceptance of the counterparty (Tyser, et al, 2007).

\subsection{Definition of $\mathrm{Ta}^{\prime} \bar{a} w u n$ :}

Ta'āwun literarily means helping each other for something, or the transfer of help from one person to the other (Ibrahim, 2004). Thus, in [al-Mā'idah :2], Allah SWT says:

(...And cooperate in righteousness and piety, but do not cooperate in sin and aggression...)

Allah SWT has enjoined mankind to cooperate in righteousness and piety with one another and avoid wrongdoing with one another. Avoiding iniquities is an act of piety to Allah SWT.

\subsubsection{Importance of $T a^{c} \bar{a} w u n$ in Islam:}

Allah SWT created man as a weak being that it is uncertain of what the future holds in terms of his existence and sustenance. Thus, the pragmatic continuity of life and the accessing of basic provisions and needs require cooperation with one and another. The principle of $T a$ ' $\bar{w}$ wun extends beyond individual relationships as its import has been adopted among community members and communities of nations to leverage on both the absolute and comparative advantages of the different states. This underscores reasons why international communities place high premium on cross border trading around the globe. For example, a farmer might need the cooperation of the person who sows for him, and those who harvest need those who make the machines. Moreover, the contemporary age requires the continuous application of $T a ' \bar{a} w u n$, especially due to the advent of information 
technology as this is transforming the world into a global village that quickly connects individuals, work, communities, businesses and governments across the globe. Imam Ibn Taimiyyah posited in one of his popular writings Al-Tis 'iniyyah that mankind cannot achieve a complete and balanced life without cooperation among themselves. He emphasized that cooperation is required among Muslims in worldly affairs as much as it is required in religious practices. Therefore, cooperation among Muslims is essential in order to achieve the purpose of vicegerency of Allah on the earth. (Ahmad bin Abdul Halìm, 1999).

\section{Murābahah Ta'āwun Contract}

\subsection{Proposed Contract Model and its Product Features:}

In this section, the operational procedures for the contract of the Murābahah-Ta'āwun product are discussed. The proposed product draws inspiration from the challenges faced by the traditional Ta'āwun exercise. Setbacks arise because of the fact that when a group of people with similar assets need to contribute an equal amount of money on a rotational basis to defray the cost of the said asset, defaults always occur from one or more of the participating members. When default occurs, it jeopardizes the interests of member(s) who is/are yet to realize the purchase of the asset for which they have made certain amounts of contributions. It is instructive to note that the situation becomes precarious when a participating member who has benefited by taking delivery of the asset, defaults with respect to his/her remaining contributions. As a corollary, practical life experiences have shown that due to the high rate of defaults, some members within the group do not get to realize their goal of owning the asset for which they had contributed. They may get back their money fully or in parts after a long process of persuasion or, in some cases, protracted court injunctions which would have defeated the reason d'etre of the Ta'āwun exercise. Thus, this model is proposed to boost the confidence of members in the Ta'äwun exercise and remove the incidence of default that generally puts conforming members of the Ta'äwun at a disadvantage position.

In this model, a group of people, who need a similar asset and have agreed to contributing certain equal amounts at regular intervals until the value of the asset is realized and delivered to the participating members on a rotational basis as agreed, approach an Islamic bank instead of the conventional arrangement where one of the members takes custody of the money. An Islamic bank is designated as the collector or custodian of the rotational $T a$ 'âwun contributions. The Islamic bank and the group enter into the Ta'âwun contract, whereby the bank buys the asset in need by the group and sells it to them at mark up on a rotational basis. Each of the participating members must operate their salary account with the designated bank such that their payments are deducted as agreed from source at regular intervals. This procedure will seek to mitigate the incidence of default. However, in the event that a member who had already taken delivery of the asset defaulted on the basis of job loss for example, the asset will be re-possessed by the bank and sold at the existing market rate. Where the proceeds from the sale is greater than the indebtedness, the difference is returned to the defaulting members. However, where there is a shortfall, the bank bears the credit risk after the efforts to retrieve the difference from the defaulting member who proves abortive. The bank makes their returns from the inputted mark up as well as the service charge for custodian purposes. In the same vein, the group gains by securing their assets and avoiding the problems associated with the default of any participating member(s).

It is instructive to note that this model is different from the normal co-operative society operations in the sense that, for the latter, the eventual use of the contributions made by members of the co-operative society is at the sole discretion of the individual members. Different members utilize their collections for different purposes which is different from the proposed Murābahah Ta'āwun contract where members 
purchase a similar asset. In a general cooperative model, the primary motive is to provide additional financing to members based on the individual member's contributions to satisfy their personal financing goals and objectives. Whereas in Murābahah Ta'āwun, there exists a mutual understanding to finance the procurement of a particular asset wherein the members maintain regular contributions for a certain period. The relationship is terminated at the expiration of the agreement where ownership is transferred to all participants after due contributions to the participating bank.

The following diagram depicts how the Murābahah Ta'awun contract could be structured. The diagram explains the key terms as well as the logical flow of the contract structure:

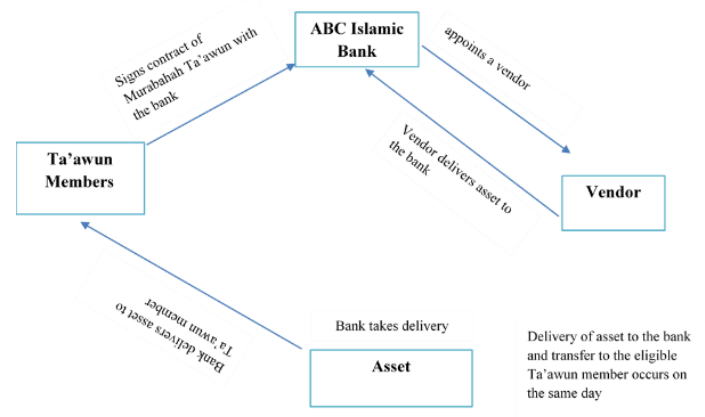

The process flow is described below:

1. Ta'āwun members appoint an Islamic bank as the custodian of their regular contributions and enter into a contractual agreement with the Islamic bank to provide a MurābaḥahTa'āwun contract for them based on their rotational contributions.

2. Once the terms and conditions of the contract is agreed upon by both parties, the bank makes an upfront payment to a vendor for the purchase of the asset.

3. The vendor delivers the asset to the bank without any encumbrance, thus transferring the right of full ownership to the bank.

4. Simultaneously, the bank transfers the asset to the Ta'âwun recipient in the ranking order provided by the Ta'āwun group.

5. The Ta'āwun members continue the contributions and get the asset on rotational basis until the last member receives his/her asset.

The inclusion of the bank as a custodian entity will rid the contract of mis-trust, mismanagement and default that have characterized the existing practice of Ta'āwun.

\subsection{Discussion on Limitations and Potential Shariah Risk of the Proposed Model:}

The proposed model seeks to facilitate more financial inclusion by promoting the purchase of assets and equipment for a group of entrepreneurs lacking a lump sum capital. By bridging this gap, the contract has the capacity to stimulate the local production of goods and services, reduce unemployment and increase the standards of living of the society. Nonetheless, the product faces the risk of default by participating member(s). However, adequate risk management mechanisms should be put in place to forestall the potential danger of defaults resulting from credit risk. Strict due diligence needs to be followed in approving the proposal of any Ta'āwun group and measures to ensure compliance of the existing terms and conditions must be effected. Significant among the list on the Know Your Customers (KYC) would be to ensure that every participating member is in a paid employment without any encumbrance and operates their salary account with the bank.

Furthermore, since the bank is expected to bear the shortfall in the event of genuine default of one of the participating members, the provision of an efficient monitoring system will raise necessary red flags of Ta' 'âwun member(s) especially the ones that have taken delivery of the asset and intend to take advantage of the system. Also, the bank and the Ta'āwun group can, as a policy, enter into a Takaful agreement to mitigate the impact of credit risk on the bank.

\section{Conclusion and Recommendation}

This paper proposed the Murābahah Ta'āwun contract as a veritable innovative Islamic financial product that has the capacity to improve financial inclusion and reduce the incidence of poverty among the community. The product connects a group of entrepreneurs in need of similar assets to expand their line of trades who are 
willing to make regular contributions towards the purchase of the asset, with an Islamic bank that acts as a custodian and financer to the Ta'āwun members. The product is unique in the sense that it focuses on the purchase of the asset which in turn has a multiplier effect on the economy. Given that participating members are known to each other and operate in the same industry, Murābaḥah Ta'āwun provides an internal mechanism that can mitigate the credit risk that seeks to be its bane.

\section{References}

Abū Dāwūd Sulaimān bin Ash-ath, Al-Sijistānī, (1420/1999). Sunan Abī Dāwūd, Hadìth No. 3383, (Saudi: International Home Ideas Corporation,.

Ahmad bin Abdul Halīm bin Abdul Salam bin Taimiyyah. (19991420), Al-Tis 'iniyyah, Vol.1, ( Al-Riyad: Maktabah AlMa'ārif,

Al-Kasānī, Abu-Bakr bin Maș 'ūd bin Ahmad 'Alāhuddin Al-Hanafi, (1986). Badāi 'u Șanāi u fĩ Tartīb Sharāi 'u, Vol.7, (Bairut: Dar Kutub Al-ilmiyyah,) p. 3163.

Al-Marāshid Al-Fiqhiyah As -Sadirah 'An Al-haihah Al-'ulyā liraqābiyyah Shariyah Lil Jihāz Al-Mașafi Wa Al-Mu 'asasāt Al-Māliyyah-Taba'at: 1, p.132.

Al-Murgiyāni, 'Alī bin Abū Bakri, (1417). Al-Hidāyah Shariḥu AlBidāyah Al-Mubtadā. Taba'ah: Al-halbī, Vol. 3 p.3.

Amin, Hanudin et al, (2011). Determinants of customers' intention to use Islamic personal financing: the case of Malaysian Islamic banks. Journal of Islamic Accounting and Business Research Vol. 2 No. 1 Emerald Group Publishing Limited, pp. 22-42.

Daryl Collins, et al., (2009). Portfolios of the Poor, published by Princeton University Press.

Heather et al. ((2007). Developing New Personal Financial Products - Some Evidence of the Role of Market Research, p. 1-12.

Haihatu Al-Muhasab Wa Al-Murāja 'h lil-Mu'asasāt Al-Māliyah AlIslāmiyah, Al-Ma'āyiri Al-Shar'iyah, No. 12, (2014/1435), P. 183-185.

http://www.alhaya.ps/pdf/2011/8/11/page17.pdf.

http://www.bloomberg.com/news/articles/2010-09-14/sarkozy-todrop-mortgage-interest-tax-deductions-push-zero-interestloans.

Ibn Kathīr, bin 'Umar, Ismā'īl. (774/1373). Tafsīr-al-Qurān-al'Azìm, Tahquiq: Sāmī bn Muhammad As-Salāmah, Dār Tībah, 1999-1420, Taba'ah. 2.

Imam, P., \& Kpodar, K. (2016). Islamic banking: Good for growth? Economic Modelling, 59(Supplement C), 387-401. doi:https://doi.org/10.1016/j.econmod.2016.08.004

Jum'ah, Muhammad 'Aliy et al.(2009). Mausu'at Fatāwā AlMu'āmalat Al-Māliyāh Li-l-Masārif Wa-l- Muāsasāt AlMāliyyah Al-Islāmiyyah Al-Mudārabah, Vol.2, (Cairo: Daru Salām, 2009).

Léon, F., \& Weill, L. (2017). Islamic banking development and access to credit. Pacific-Basin Finance Journal. doi:https://doi.org/10.1016/j.pacfin.2017.04.010

Majma'u Al-lughah Al-'Arabiyyah bi-Al-Qāhirah, Al-M'ujamu AlWasīt, (2010), P. 638.

Triki, T \& Faye, I. (2013). Financial Inclusion in Africa, African Development bank, Ghana.
Tyser, C.R. et al, (2007). The Mejelle, Being An English Translation of Mujallah El-Ahkam-l-Adliyah and A Complete Code of Islamic Civil Law, (Malaysia: The Other Press Sdn Bhd).

Young, E. (2013). World Islamic Banking Competitiveness Report, $2013 . \quad$ Report

http://www.bloomberg.com/news/articles/2010-09-

14/sarkozy-to-drop-mortgage-interest-tax-deductionspush-zero-interest-loans http://www.alhaya.ps/pdf/2011/8/11/page17.pdf

ISRA, (2010). Compendium for Islamic Financial Terms, ArabicEnglish, Malaysia: International Shariah Research Academy for Academy Finance ISRA, (2010), p. 71.

Ahmad 'Ali 'Abdullah, (1987), Al-Murābahah: Usuluha WaAhkāmuha wa Tațbiqātuha fi Al-Masārif Al-Islāmiyyah, p.14.

Muhammad 'Ali Al-Tahānahawī, (1996). Mausū'āh Al-'ulūm AlIslāmiyah: kashāf Islāhāt Al-Funūn, Vol.2, p.538.

Ahmad bin Muhammad bin Hanbalī bin Hilāl bin Asad, Musnad AlImām Al-Ahmad, (Bairut: Daru Ihyā At-Turāth Al-Arabi, 1993-1414). No. 61814.

Ahmad 'Ali 'Abdullah, Al-Murābahah, P.24, see: Jamālud-Din 'Abdullah bin Yūsuf Al-zaila'i, Nașab Al-rāyah fi Takhrīj Ahādìth Al-Hidāyah, Kitāb Al-Buyū', (Al-Su'ūdiyah: Daru Al-Hadith, 1995-1415) 